\title{
On Ai Siqi's Popular Philosophy
}

\author{
Chen Chunying \\ Philosophy School of Zhongnan University of Economics and Law
}

\begin{abstract}
Popular Philosophy is an important representative work of the renowned Marxist philosopher Ai Siqi. As a concise popular reading of Marxist basic theory, it explains three aspects, namely materialism, epistemology and dialectics to the people with extremely plain, vivid and popular language. As the foundation work for popularizing Marxist philosophy in China, it is a particularly important resource to deepen the development of Marxist philosophy in modern and contemporary times. Therefore, it is of great importance and profound significance to study this work. In this essay, the author analyzes the writing background, main content, major characteristics and the significance of Popular Philosophy.
\end{abstract}

Keywords-Ai Siqi, Popular Philosophy, popularization of philosophy, Marxist philosophy

Like a torch in the revolution, Popular Philosophy lit up the way forward in the dark and enlightened thousands of young people on the road of revolution. "Popular Philosophy crushed the ideological defense of Three People's Principles", lamented Chiang Kai-shek in the Civil War period, admitting that his failure is because of the loss of people's trust and support. Mao Tse-tung once said that "the general principles of Marxism \& Leninism which reflects the struggles of proletarian all over the world", after being introduced into China, "were proved to be an invincible weapon for Chinese people when integrated into the actual revolutions and struggles by the Chinese proletarians and the people." [1] Popular Philosophy is just such a powerful theoretical weapon. As a representative work of Marxism popularization, Popular Philosophy pioneered the success of Marxism popularization. Besides, it serves as important reference and inspiration for the popularization of Marxism philosophy under the new circumstances. Therefore, it is necessary for us to study the work in modern times.

\section{Writing BACKGROUND OF POPULAR PHILOSOPHY}

Written during the war of Chinese people's resistance against Japanese aggression, Popular Philosophy has met the practical needs of the Chinese revolution and complied with the trend of the time and the law of historical development. Besides, it took shape in the contest against various reactionary theories.

First, Popular Philosophy was urgently needed by the Chinese revolution. In 1931, Japan initiated the "September $18^{\text {th }}$ Incident", which made China fall into serious national crisis. Under such a circumstance. Chinese people were generally confused about the fate of the country against the severe social context. At such a time, the guidance of advanced proletarian ideology of Marxism was needed. What's more urgently required was for Marxism thoughts to be known and understood by the people. Therefore, the popularization of Marxism became a pressing issue confronted with the people. In order to save the country from national crisis, patriots with lofty aspirations tried out political reforms and revolutions successively. However, the successive failure of the Hundred-Day Reform and the 1911 Revolution revealed it to us that a powerful ideological weapon was demanded to direct our revolution. While China was trapped in dilemma, the success of Russia's October Revolution brought us valuable Marxism which as the ideological weapon of the proletariat attracted the attention of increasingly more Chinese intellectuals. Before the May $4^{\text {th }}$ Movement, most people in China did not know Marxism or even misunderstood it. However, as people found more of the greatness of Marxism after the May $4^{\text {th }}$ Movement, Li Dazhao, Chen Duxiu, Li Da upheld the flag of Marxism one after another. At that time, Ai Siqi was also an important representative among those who accepted the advanced Marxism. In the Resolutions on Party Building adopted on the First Party Congress of the Soviet Area in 1931, the following problems were pointed out: "party education and ideological struggle are insufficient, with some ordinary party members still holding very shallow understanding of the Party's basic claims and important strategies; part of party members have not recognized the class consciousness of the Party, taking the Party as a party of workers\& farmers or the poor and trusting more the individuals in the party rather than the organization; the systematic education of the basic knowledge of Marxism \& Leninism did not raise due attention from the Party; therefore, education of the basic theory of Marxism \& Leninism must be strengthened." [2] This proved that the ideological construction required by the revolution could be carried out only when Marxism was accepted by more and more people and the popularization of it was realized. It was just in response to such need that Popular Philosophy came into being.

Second, Popular Philosophy was urgently needed for fighting against various reactionary thoughts and doctrines. In Marxism ideology, historical materialism is the cornerstone and class struggle theory is the key. Yet in the process of exploring the road for the Chinese revolution with the general principles of historical materialism, three debates appeared, namely, the "Problems and Doctrines" debate, the debate against Pseudo-Socialism and that against Anarchism. In the name of exploring China's development path, Zhang Dongsun publicly denied socialism and praised capitalism. In Guild Socialism advocated by him, it was claimed that in China capitalism should be first developed as a foundation for socialism construction. Anarchism opposed all kinds of states and politics, disapproved all laws and all powers especially the proletarian dictatorship and advocated absolute freedom. During the early stage of the propagation of Marxist 
philosophy in China, there was a "debate between science and metaphysics". The metaphysics school represented by Zhang Junmai and Liang Qichao held the opinion that "science cannot solve problems concerning the outlook on life because science and the outlook on life are of two different worlds and the former works only in the material world." However, the science school represented by Ding Wenjiang pointed out that "science can dominate one's outlook on life." In contrast, influenced by Machism to some extent, Ding Wenjiang advocated "Skeptical Idealism". These thoughts are subjective and extreme even in our view today. During the spread of materialist dialectics in the 1930s, there were also opposite theories. Zhang Dongsun was the first one to attack materialist dialectics. He began with criticizing Hegel's dialectics, trying to deny Marx through denying Hegel, and strongly rejected the basic laws of materialist dialectics. Ye Qing propagated false Marxist philosophy. In the debates on the "orientation of philosophy" and other issues, he even put forward such erroneous and reactionary theories as "unity of philosophy and science", "integration of materialism and idealism" and "philosophical elimination", which essentially advocated the integration of science and philosophy, denied philosophical ontology and made philosophy empirical and scientized. These reactionary thoughts and doctrines all emerged in the process of the spread of Marxism philosophy in China. Many of them came from the misinterpretation and misunderstanding of Marxism. In this case, Popular Philosophy became a pressing need for fighting against various reactionary thoughts and doctrines.

Last, Popular Philosophy was written under the influence of "Popularization of Literature" and "Popularization of Social Sciences". In the spring of 1930, Guo Moruo, Lu XunXia Yan and other writers carried out the first discussion on literature popularization through publications including Popular Literature, Pioneers and Art edited by left-wing writers. They realized that it's urgent and important to popularize literature after founding that revolutionary literature works were not popular among workers and peasants yet the popular literature with feudal elements was widely spread. Literature Popularization Movement strengthened the connection between new literature creation and the public, broadening the range of readers from intellectuals and youth students to part of office workers, salespersons and the citizen class. Since then, the literature popularization has been developed right here. It was not until the Yan'an Forum on Literature and Art in 1942 that literature popularization was generally achieved in the anti-Japanese democratic base areas. Spreading of literature popularization stimulated "popularization of social sciences" which began changing from slogans to practices. "Popularization of Literature" and "Popularization of Social Sciences" laid a foundation for "Philosophy Popularization" and made it possible.

\section{Main Content of Public Philosophy}

Public Philosophy consists of 22 pieces in 5 chapters as follows: introduction, dualism and materialism, epistemology of dialectical materialism, basic laws of materialist dialectics and several concepts on materialist dialectics. The main contents include three aspects: materialism, epistemology and dialectics.

\section{A. Materialism}

Referring to materialism, Ai Siqi distinguished it from Idealism at first. It is pointed in the text that "in philosophy idealism refers to such knowledge and opinions that exaggerate the subjective and spiritual things, take them as the superlative and unique objects in the world and deny the existence of objectiveness and matter." [3] In this work, those who believe in fatalism, despotism, fascism and "the theory of rapid victory" are all regarded as idealists. After the discrimination, the writer wrote that the fundamental idea of materialism is recognizing the independent existence of matter and its own laws and admitting that matter is primary while mind is secondary and derives from matter. In detailed analysis of idealism and materialism, he thought that idealism could be divided into subjective idealism and objective idealism. The former took all the things in the world as within people's mind while the latter took the world as the result of gods' feelings and thoughts. Materialism was divided into mechanical materialism and dialectical materialism. According to the opinion of Ai Siqi, mechanical materialism does not recognize the changes in old and new things or the forming and elimination of matter. Therefore, it is still a type of metaphysical materialism. In contrast, dialectical materialism is the revolutionary world view of Marxists and is the philosophy of the proletariat. In detailed analysis of dialectical materialism, Ai Siqi mentioned that dialectical materialism recognizes the changes of the nature of things as well as the generation and elimination law of things.

\section{B. Epistemology}

Ai Siqi elaborated epistemology from 5 aspects: reflectionism, contradiction between perceptual knowledge and conceptual knowledge, relationship between perceptual knowledge and conceptual knowledge, knowledge and practice and the theory of truth. Talking about reflectionism, Ai Siqi took camera for an example, demonstrating that people's knowledge was the reflection of the external world. Then, can people find the truth of external objects through perception? This is a question to be answered. Under agnosticism, the answer is no, while under materialism it is yes. Ai Siqi held the opinion that every perception of us could reflect one aspect or part of the truth of the external world. Elaborating the contradictions between perceptual knowledge and conceptual knowledge, he wrote that the former was gained through sensory organs and could only recognize the external characteristics of things while the latter could enable us to understand the inherent characteristics of things. As far as $\mathrm{Ai}$ was concerned, the relationship between the two kinds of knowledge was like that between father and son. As he wrote, "now the relationship between perceptual knowledge and conceptual knowledge seems like that between father and son rather than between husband and wife or between brothers." ${ }^{[4]}$ According to him, perceptual knowledge is like a bridge leading to conceptual knowledge. The latter can only be reached by accumulating large amount of the former. Yet people can still see certain relationships among things and the laws of development of things through the former. When it 
comes to the theory of truth, Ai first mentioned that the school of subjective truth does not recognize the existence of objective standards judging whether one's perception is true or false. Yet the materialists recognize that objective things should be the criteria judging whether one's perception is true or false. By this, the materialists recognize the existence of objective truth. After that, he analyzed the relativity of truth which means that one's perception is true only under certain circumstances, and relative truth as well as absolute truth. Finally, he mentioned that every perception of us is relative but tending to reach the end of absolute truth, which is the unity of relative truth and absolute truth.

\section{Dialectics}

Ai Siqi introduced dialectics at length. He explained dialectics from two aspects: the basic laws of and the several concepts on dialectics. In Ai's work, the basic laws of dialectics are divided into five parts: the law of general and organic relation of things, the law of the motion and development of things, the law of interchange of quality and quantity, the law of the unity of opposites and the law of the negation of the negation. General and organic relation of things is the first major law of dialectics. In the text about this law, Ai wrote that things are not isolated and they all have certain relations with things around. Here the relations refer to interdependence and mutual constraints of things. With respect to development of things, the writer mentioned that it's a metaphysical idea to take motions of the all the things as changes in quantity and position caused by external power, for things have their own law of motion and development. Ai began his explanation of the third law by taking the collapse of Leifeng Pagoda for an example. He mentioned the two changes before the collapse: quantitative change and qualitative change. Quantity and quality are the inherent two aspects of everything. Quantitative change and qualitative change are closely connected. After this, Ai introduced the last two laws of dialectics, namely the law of the unity of opposites and the law of the negation of the negation. At the final part of Popular Philosophy, Ai touched on the several concepts on dialectics, mainly these five couples: appearance and essence, form and content, cause and effect, contingency and inevitability as well as possibility and actuality. In terms of the first couple of concepts, the writer thought that everything has two sides: the changing external shape called appearance and the certain internal relation called essence. Yet the contradiction between these two aspects is not absolute, for the former is an expression of the latter and is inseparable from the latter. As for the concepts of form and content, $\mathrm{Ai}$ mentioned that everything has its content and certain form. Things develop in certain forms and the whole process of development is their content. Later, $\mathrm{Ai}$ analyzed the other three couples of concepts in a similar way.

\section{MAIN Characteristics of POPUlaR PhILOSOPHY}

This work has combined philosophy propagation with concerns of national destiny and the people's sufferings. Those who have read the work may find that the writer would usually combine the philosophical principles with relevant problems in the revolution or explain those problems with popular philosophical principles after elaboration of each principle. For instance, referring to the two categories of philosophy, Ai mentioned that "fatalism is the world view used by prominent landowners and the big bourgeoisie to propagate fascism and is also the ideological weapons used by the feudal landlord class to consolidate their autocracy while hedonism is the idea of part of landlords and bourgeoisie who live a wandering life based on exploitation and pessimism is a weak thought with those declining social classes as its basis." ${ }^{[5]}$ With respect to materialism and idealism, Ai wrote that "the so called philosophies of the reactionary prominent landowners and bureaucratic bourgeoisie in China such as the Vitalism of Chen Lifu and Chiang Kai-shek's Philosophy of Practice with Earnestness, all belong to idealism, while the world view and ideological method of the China's labor class and the CPC who determinedly lead the Chinese people in the revolution is Marxist dialectical materialism." [6] The above shows that Ai Siqi does not only explain philosophical principles and his aim is to familiarize the public with the development and situation of the revolution through these philosophical thoughts. It's also the final end of this work to guide the revolution with philosophy and lay an ideological foundation for the success of the revolution.

In this work, the writer used many vivid real cases to demonstrate the basic principles of philosophy, such as "two troops fighting against each other", "a farewell between Hitler and Chaplin" and "How was Yue Fei killed". In the fifth chapter, with respect to the concepts of appearance and essence, Ai took the "seventy-two changes of Sun Wukong" in Pilgrimage to the West as an example. Yet whatever he changes to, his aim is to resist the ruling of the gods in the heaven. Meanwhile, the writer took another example: "You have made a friend and he did not know you at all before you are friends. Is it not a change to become friends from strangers? During a time you two appear to be very close with consistent ideas. Yet at another time, you have some disputes and even quarrel with each other. Is it not another change? As a result, you get confused and have no idea how to treat him. To take him as friend or to be against him?" [7] Such cases and examples appear quite frequent in the work. Through these cases, we can better understand and have a deeper impression of specific principles without feeling hard.

As for the language form of this work, the writer explained philosophical principles and problems with common and popular language used by the people. In the catalogue, we can find many idioms and sayings frequently used by common people, such as "God knows", "turning pale at the mention of a tiger", "cats are born to catch mice", "turning out to be family" and "friend or wolf". Since common people have not received adequate education while philosophy principles are thinking-demanding, they can hardly understand those philosophy principles if taught in the way of a textbook. Yet if the language is popularized by using such idioms and sayings, it is easier for people to understand and the popularization of philosophy can be carried out successfully. Referring to the concept of purposiveness, Ai wrote: "Water is arranged for people to drink, cats are born to catch mice and the paws of tigers and leopards are used for catching small animals; in other words, things are born with certain purpose." ${ }^{[8]}$ Turning 
to the theory of truth, Ai took "friend or wolf" as the title. "The US imperialists have left Chinese people two opposite impressions. On the one hand, they look increasingly like wolves in the eyes of common Chinese people; on the other, the prominent landowners and the big bourgeoisie led by Chiang Kai-shek insist on regarding the US imperialists as good friends of the Chinese people. Which one of these two opposite impressions is right? In response to our reply before, the answer is "the wolf impression'." ${ }^{[9]}$ It can be said that the plain language makes the work much more interesting and popular among common people.

\section{Significance of Popular Philosophy}

Popular Philosophy have promoted the popularization of Marxism and enhanced the impact of Marxism among the public. It is different from other philosophical readings mainly in that its language and content are popular. A few philosophical readings have been issued before, yet without sound reactions from the public. The reason is that these readings are usually hard to understand and thus unattractive to the people. Yet this work made it possible for common people to learn philosophical principles. The plain language style enables the public to know what Marxist philosophy is, sort out the experience of developing Marxist philosophy and explore the laws in Marxist philosophy, exerting great influence on people's thoughts. Previously we have mentioned that the final purpose of Marxist philosophy is not to make the people understand the principles of it but to facilitate them to guide their practice with these principles and recognize situations of the revolution. This is what the people expect and is also a great breakthrough of this book. By taking people's practice as the basis of theoretical study and combining the theory with the practice in China, Popular Philosophy has gained widely support from the people for Marxist philosophy and initiated the popularization of it in China.

As a successful exploration of Marxist philosophy's popularization in China, Popular Philosophy has encouraged those struggling for the popularization of Marxist philosophy. Among the first Chinese works introducing Marxism, this work has identified a road for the popularization and realization of Marxist philosophy. Based on the practical need of the people, it creatively explains Marxist philosophy in a way appealing to them, which makes the philosophy easily accepted by them. Mao Tse-tung once made a pertinent comment on Ai Siqi, saying that "with his distinguished contribution in the popularization of philosophy, our colleague Ai Siqi has devoted his life into propagating and developing Marxist philosophy and transformed philosophy of the philosopher into weapons of the people." ${ }^{10]}$ In this work, the writer took real cases from life to demonstrate certain concepts and principles of Marxist philosophy, explained problems appearing in China's revolution and real life with the philosophical principles and identified a road for Marxism popularization in China by guiding our practice with the position, opinions and methods in Marxist philosophy. "With his work, Ai Siqi gave a comprehensive and systematic introduction to the basic principles of Marxist philosophy early in a creative way acceptable to the people; in this case, he pioneered the popularization of philosophy and made the basic ideas of dialectical materialism and historical materialism widely accepted by the people, contributing much to the victory of China's revolution and the propagation in China; therefore, his work is quite innovative and successful in exploring the popularization of Marxism in China." [11]

Popular Philosophy provides us with inspirations in popularizing Marxism in modern times. The work stands out among philosophical readings just because of its popular language style appealing and acceptable to the people. In the new era, we need better strategies to cope with problems appearing in the process of the popularization of Marxist philosophy. At present, with fast changes in information technology and Internet technology, previous ways of Marxism propagation have been too old and abandoned by the time. Therefore, we must innovate in the methods of propagating Marxism in the new era. In addition, during the propagation, we must always understand the people's need and observe the changes of them. What's more, we must recognize and consider the people's principal position and their pioneering spirit while addressing problems. We have mentioned that science and technology is undergoing dynamic changes and traditional methods of propagating philosophy have long been outdated. Now we can try promoting Marxism popularization through the Internet and new media and make full use of new modern media to innovate in Marxist theory. Certainly, we need a number of scholars and researchers devoted in Marxism study and propagation. With these talents, we can have more in-depth study and understanding of Marxist philosophy and lead more people to participate in propagating it. That is, we need some new ways to continuously promote the popularization of Marxist philosophy in modern times after Popular Philosophy.

\section{REFERENCES}

[1] Mao Tse-tung. Selected Works of Mao Tse-tung, Volume III. Beijing: People's Publishing House, 1991, Page 1094.

[2] Party Building Resolutions. Passed on the First Party Congress of Central Soviet Area.

[3] Ai Siqi. Popular Philosophy, Collected Works of Ai Siqi. Beijing, People's Publishing House, 1981.

[4] $\mathrm{Hu}$ Yurong. Let philosophy be close to reality- Popular Philosophy by Ai Siqi and its Practical Significance. Journal of Kunming University, 2008. Phase I, Volume 30, Page 5-8.

[5] Hu Yurong, Let philosophy be close to reality- Popular Philosophy by Ai Siqi and its Practical Significance. Journal of Kunming University, 2008. Phase I, Volume 30, Page 5-8.

[6] Mo Wenhua. Pioneer of Philosophy Popularization - Ai Siqi; Reminisce and Exploration: Commemoration of Collected Works of Ai Siqi (19812008). Beijing, Central Party School Publishing House, 2010.

[7] Zhang Dongsun. Overall Review of Materialist Dialectics; Selected Works of Chinese Modern Philosophy. Shanghai, Fudan University Press, 1989

[8] Ai Siqi, Intuitionism and Rationalism; Collected Works of Ai Siqi, Volume I. Beijing, People's publishing House, 1981.

[9] Ai Siqi, Chinese Philosophy Trend in the Past 22 Years; Collected Works of Ai Siqi, Volume I. Beijing, People's publishing House, 1981.

[10] Ai Siqi, On the Reversal of Hegel 's Philosophy; Collected Works of Ai Siqi, Volume I. Beijing, People's Publishing House, 1981.

[11] Ai Siqi, The Real Face of Objectivism; Collected Works of Ai Siqi, Volume I. Beijing, People's publishing House, 1981. 
[12] Ai Siqi, Contradiction between Rationalism and Intuitionism; Collected Works of Ai Siqi, Volume I. Beijing, People's publishing House, 1981.

[13] Qu Qiubai. Introduction to Social Philosophy; Collected Works of Qu Qiubai, Volume II of Political Theories. Beijing, People's Publishing House, 1988.
[14] Qu Qiubai. Cosmological View of Materialism,;Collected Works of Qu Qiubai, Volume IV of Political Theories. Beijing, People's Publishing House, 1993.

[15] Mao Tse-tung. Dialectical materialism (lecture outline); Selected Works of Mao Zedong 's Works (First Part). Beijing, Central Party Literature Press, 2003. 